\title{
NILAI-NILAI MORAL CERITA RAKYAT DI BANTEN
}

\author{
Hidayah Budi Qur'ani*1, Eggy Fajar Andalas*² \\ ${ }^{1,2}$ Universitas Muhammadiyah Malang \\ ${ }^{1,2}$ Program Studi Pendidikan Bahasa dan Sastra Indonesia, Fakultas Keguruan dan Ilmu \\ Pendidikan, Malang \\ e-mail: *11qurani@umm.ac.id, ${ }^{2}$ eggy@umm.ac.id
}

\begin{abstract}
Abstrak
Penelitian ini membahas mengenai bentuk-bentuk nilai moral yang ada di dalam cerita rakyat di Banten. Moral merupakan pengajaran baik atau buruk perbuatan dan tingkah laku. Moral dapat digunakan sebagai alat ukur untuk menentukan baik dan buruknya akhlak atau perilaku seseorang. Cerita rakyat adalah sebuah cerita yang berkembang dan hidup di suatu masyarakat. Cerita rakyat pada zaman dahulu disebarkan dari mulut ke mulut, meskipun pada saat ini sudah banyak cerita rakyat yang ditulis. Di dalam sebuah cerita rakyat, terdapat nilai moral budi pekerti yang digambarkan melalui cerita atau tokoh-tokohnya. Nilai moral tersebut dapat dijadikan sebagai contoh dalam kehidupan sehari-hari. Metode yang digunakan dalam penelitian ini adalah deksriptif kualitatif Sumber data dalam penelitian ini adalah enam cerita rakyat dari Banten diantaranya Masjid Terate Udik yang Keramat, Legenda Batu Kuwung, Legenda Gunung Pinang, Pangeran Pande Gelang dan Putri Cadasari, Legenda Tanjung Lesung, Legenda Prasasti Mujul, dan Sultan Maulana Hasanuddin. Hasil dari penelitian ini adalah bentuk-bentuk nilai moral yang menunjukkan sikap terhadap sesama manusia diantaranya (1) saling membantu, (2) jujur, (3) menghargai orang lain, (4) bertanggung jawab, (5) menghargai perempuan, dan (6) menghormati orang tua.
\end{abstract}

Kata kunci: nilai moral, cerita rakyat, banten

\section{A. PENDAHULUAN}

Sastra merupakan sebuah teks yang berisi pedoman atau instruksi dan mengandung suatu pengajaran. Sastra merupakan sebuah karya tulis yang berbeda dengan karya tulis lainnya. Perbedaan tersebut treletak pada cirinya diantaranya katakata, estetika, dan keaslian. Sastra juga memberikan pengetahuan dan wawasan umum mengenai manusia, sosial, lingkungan, dan gambaran lainnya dengan gaya yang khas. Dalam Bahasa Indonesia, istilah sastra merujuk pada sebuah karya yang mengandung unsur imajinatif dan keindahan yang dibuat oleh pengarang dengan mengimitasi atau meniru kondisi masyarakat yang sesungguhnya.

Seiring perkembangan zaman, terdapat dua penggolongan sastra yang ada di Indonesia. Kedua penggolongan tersebut adalah sastra tulis dan sastra lisan. Sastra tulis merujuk pada karya sastra dalam bentuk tulisan dan sastra lisan merujuk pada karya sastra yang persebarannya melalui oral atau dari mulut ke mulut. Akan tetapi, sejauh ini sudah banyak sastra lisan yang mulai ditulis dan menjadi bagian dari sastra tulis. 
Salah satu bentuk pengajaran yang dapat ditemukan dalam cerita rakyat adalah nilai-nilai moral. Moralitas atau yang sering kita sebut moral merupakan tindakan manusia yang memiliki nilai-nilai baik. Moral merupakan sebuah nilai keabsolutan yang dibentuk dari perilaku sosial yang ada disekitar atau di lingkungan tersebut (Nurdyansyah, 2018: 12).

Nilai moral yang dikemukakan di atas, juga terdapat dalam cerita rakyat di Banten. Dalam cerita rakyat di Banten, terdapat kisah-kisah yang dapat diambil nilainilai baik dan buruk. Nilai baik dan buruk dapat digunakan oleh pembaca sebagai contoh dan pedoman dalam kehidupan sehari-hari. Nilai-nilai moral tersebut dapat juga digunakan sebagai pembelajaran agar tidak terjerumus dalam hal-hal yang dapat memberikan dampak negatif bagi kehidupan. Selain itu, nilai-nilai moral yang terkandung dalam cerita rakyat di Banten dapat dijadikan media untuk memberikan contoh baik kepada anak-anak.

Ada beberapa alasan dipilihnya cerita rakyat di Banten sebagai bahan kajian dalam penelitian ini. Pertama, cerita rakyat di Banten masih belum banyak diulas secara keseluruhan (semua cerita rakyat), kedua mengenalkan cerita rakyat di Banten kepada masyarakat luas yang belum mengenal, dan ketiga cerita rakyat di Banten banyak sekali mengandung nilai-nilai moral yang dapat diambil oleh pembaca sebagai pembelajaran dalam kehidupan. Oleh karena itu, rumusan masalah dalam penelitian ini adalah bagaimana bentuk-bentuk nilai moral yang terdapat dalam cerita rakyat di Banten?. Tujuan penelitian ini adalah mendeskripsikan bentuk-bentuk moral yang terdapat dalam cerita rakyet di Banten.

Penelitian mengenai nilai moral sudah pernah dibahas oleh peneliti sebelumnya. Diantaranya penelitian yang dilakukan oleh Arrows (2016), Mada dan Syukur (2017), dan Simamora (2018). Ketiga penelitian tersebut mengungkapkan bahwa nilai moral sangat penting untuk diterapkan dalam kehidupan sehari-hari karena dapat memberikan dampao positif bagi lingkungan dan perilaku manusia. Dalam cerita rakyat juga digambarkan bagaimana moral dapat memberikan dampak positif bagi diri sendiri maupun hubungan dengan Tuhan, dan hubungan dengan orang lain.

Perbedaan penelitian ini dengan penelitian sebelumnya terletak pada objek kajian dan fokus kajian. Objek kajian pada penelitian sebelumnya tidak membahas mengenai cerita rakyat di Banten. Pada penelitian sebelumnya fokus kajian terhadap 
nilai diri sendiri, masyarakat, dan Tuhan. Pada penelitian ini fokus kajian terletak pada nilai moral terhadap sesama manusia. Hal tersebut dipilih karena cerita rakyat merupakan salah satu media yang dapat digunakan untuk memberikan pelajaran yang baik bagi masyarakat, khusunya orang tua dan anak-anak. Oleh karena itu, untuk memberikan contoh yang baik bagi anak-anak untuk berinteraksi yang baik dan santun terhadap sesama, orang tua dapat memberikan contoh bacaan cerita rakyat.

Dari uraian di atas dapat disimpulkan bahwa penelitian yang berjudul Nilai-Nilai Moral Cerita Rakyat di Banten sangat penting untuk dilakukan. Karena, dengan adanya nilai moral terhadap sesama manusia yang digambarkan dalam cerita rakyat di Banten, diharapkan dapat memberikan gambaran kepada pembaca untuk lebih peka terhadap lingkungan sekitar. Sehingga, dapat ditarik rumusan masalah pada penelitian ini yaitu bentuk-bentuk nilai moral yang terdapat dalam cerita rakyat di Banten. Tujuan dari penelitian ini adalah mendeskripsikan bentuk-bentuk nilai moral yang terdapat dalam cerita rakyat di Banten.

\section{B. KAJIAN TEORI}

Cerita rakyat merupakan salah satu bentuk sastra lisan dari zaman dahulu yang diwariskan secara turun-temurun dari generasi ke generasi, berkembang di kalangan rakyat, tidak diketahui nama pengarangnya. Kemudian cerita rakyat juga dianggap sebagai kepercayaan yang telah mentradisi dalam masyarakat, dipertahankan oleh masyarakat pemilik-nya, dan merupakan salah satu bagian dari folklore (Youpika dan Zuchdi, 2016:51).

Moral merupakan pengetahuan yang menyangkut budi pekerti manusia yang beradab. Moral juga berarti ajaran yang baik dan buruk perbuatan, dan kelakuan (akhlak). Nilai moral dapat diperoleh di dalam nilai moralitas. Moralitas adalah kesesuaian sikap dan perbuatan dengan hukum atau norma batiniah, yakni dipandang sebagai kewajiban (Eliastuti, 2017: 42).

Pendidikan moral menunjukkan peraturan-peraturan tingkah laku dan adat istiadat untuk menjunjung tinggi budi pekerti dan nilai susila, sehingga di dalam masyarakat sangat mengutamakan nilai akhlak atau tingkah laku. Tingkah laku tersebut yang akan menentukan kedudukan seseorang di dalam masyarakat (Nurfajiah, 2014: 25). 
Dari uraian di atas dapat disimpulkan bahwa moral merupakan pengajaran baik atau buruk perbuatan dan tingkah laku. Moral dapat digunakan sebagai alat ukur untuk menentukan baik dan buruknya akhlak atau perilaku seseorang. Oleh karena itu, pendidikan moral sangat penting untuk diajarkan karena menyangkut masa depan generasi selanjutnya.

Menurut (Suparno, dkk, 2002: 29), budi pekerti dapat diartikan sebagai nilai moralitas manusia yang disadari dan dilakukan dalam tindakan nyata. Di sini ada unsur proses pembentukan nilai tersebut dan sikap yang didasari pada pengetahuan mengapa nilai itu dilakukan. Dan semua nilai nilai moralitas yang disadari dan dilakukan itu semua bertujuan untuk membantu manusia menjadi manusia yang lebih utuh.

Seperti yang telah dikemukakan oleh Suparno, dkk mengenai pengertian dari budi pekerti yang merupakan bagian dari nilai moral. Maka, dapat disimpulkan bahwa menurut Suparno, dkk (2002: 30-35) terdapat delapan bentuk nilai moral, diantaranya:

a. Sikap Penghargaan Terhadap Sesama Manusia. Penghargaan bahwa pribadi manusia itu bernilai, tidak boleh direndahkan atau disingkirkan harus dikembangkan. Setiap manusia, sebagai sesama ciptaan Tuhan, siapapun mereka, adalah bernilai. Inilah yang menjadi hak asasi manusia.

b. Penghargaan terhadap perempuan. Salah satu wujud penghargaan terhadap setiap manusia adalah penghargaan terhadap perempuan (gender). Persoalan ini menjadi penting di zaman ini agar perempuan tidak didiskriminasikan terhadap laki-laki. Perempuan dan laki-laki diciptakan sederajat, mereka sama-sama bernilai di depan Tuhan.

c. Menghargai Gagasan Orang Lain Serta Mau Hidup Bersama Orang Lain Yang Berbeda. Sikap ini jelas sangat membantu kita menjadi manusia karena memanusiakan orang lain. Dalam dunia Indonesia yang sedang mencari bentuk demokrasi, sikap-sikap ini jelas diperlukan. Apalagi sikap rela hidup bersama, meski lain gagasan, lain ideology perlu ditekankan. Kita rela hidup bersama dalam perbedaan karena perbedaan adalah keadaan asasi kita.

d. Sikap Tenggang Rasa, Berlaku Adil, Suka Mengabdi, Ramah, Setia, Sopan, dan Tepat Janji. Sikap-sikap ini jelas membantu orang dalam berelasi dengan orang lain dan hidup bersama orang lain. Berlaku adil dan tenggang rasa merupakan wujud penghargaan kita terhadap orang lain, terhadap sesama kita. Sikap jujur sangat 
penting ditekankan, terlebih dalam situasi Indonesia yang menjadi juara korupsi di dunia. Di dalam sekolah kejujuran dapt diwujudkan dalam tindakan seperti, tidak menyontek tidak melakukan plagiat, tidak korupsi, tidak main belakang, tidak membohongi teman, dan lain-lain.

e. Sikap Demokratis: Non Diskriminatif dan Non Represif. Dalam negara yang demokratis, orang tidak boleh didiskriminasikan berdasarkan suku, agama, tingkat sosial, maupun level pendidikan. Orang mendaptkan perlakuan sama dalam mendapatkan pelayanan masyarakat dan negara seperti dalam hal ini pendidikan dan hukum. Orang juga tidak boleh ditindas oleh orang atau kelompok lain, tetapi perlu dihargai. Penindasan dalam bentuk apa pun dianggap melanggar nilai kemanusiaan. Sikap ini perlu ditanamkan pada anak didik sehingga mereka sejak kecil tidak mendiskriminasikan dan menindas orang lain atau teman lain.

f. Penghormatan Terhadap Sexualitas dan Hidup Berkeluarga. Nilai ini juga perlu dikenalkan terutama agar anak didik menghargai dan menggunakan sexualitas secara benar dan tidak membuat pelecehan sexual dan menyalahgunakannya.

g. Sikap Berbangsa dan Cinta Tanah Air. Sikap cinta terhadap tanah air, rela ikut membangun bersama hidup berbangsa, terlibat dalam hidup bersama untuk membangun negara; taat kepada hukum yang berlaku demi lancarnya hidup bersama, semuanya perlu ditekankan dalam rangka membangun bangsa ini.

h. Nilai Adat dan Aturan Sopan Santun. Beberapa budaya mempunyai nilai hidup bersama yang dianggap baik. Nilai ini pun perlu ditawarkan kepada anak didik agar mereka dapat masuk dalam budaya mereka dan juga dapat mengerti budaya serta orang-orang mereka. Nilai sopan santun memang tidak berlaku umum, tetapi lebih ditentukan daerah masing-masing. Maka nilainya relatif. Namun meski relatif mempunyai kebaikan juga yang perlu diperkenalkan.

\section{METODE PENELITIAN}

Jenis penelitian ini adalah kualitatif. Pendekatan yang digunakan dalam penelitian ini adalah struktural. Pendekatan struktural digunakan untuk menghasilkan bentukbentuk nilai moral yang terdapat dalam cerita rakyat di Banten. Pendekatan struktural merupakan sebuah analisis yang membedah unsur-unsur karya sastra sebagai sebuah karya yang otonom. Unsur-unsur tersebut diantaranya unsur intrinsik dan ekstrinsik. 
Sumber data dalam penelitian ini adalah enam cerita rakyat dari Banten yang diambil dari laman http://ceritarakyatnusantara.com/id/browse/335-Banten\#. Keenam judul cerita rakyat diantaranya Masjid Terate Udik yang Keramat, Legenda Batu Kuwung, Legenda Gunung Pinang, Pangeran Pande Gelang dan Putri Cadasari, Legenda Tanjung Lesung, Legenda Prasasti Mujul, dan Sultan Maulana Hasanuddin. Data dalam penelitian ini adalah satuan cerita atau sekuen yang menggambarkan bentuk-bentuk nilai moral cerita rakyat di Banten.

Teknik pengumpulan data dalam penelitian ini menggunakan metode dokumentasi, yaitu mencari data mengenai hal-hal atau variabel yang berupa catatan, transkip, buku, dan dokumen lain yang relevan dengan penelitian. Teknik analisis data dalam penelitian ini dilakukan secara berkesinambungan dari awal sampai akhir dengan menggunakan teknik interaktif seperti yang dikemukan oleh Miles dan Huberman yaitu (1) reduksi data, yaitu membuat abstraksi seluruh data yang diperoleh dari seluruh catatan lapangan hasil observasi wawancara dan pengkajian dokumen. (2) penyajian data, yaitu sekumpulan informasi tersusun yang memberi kemungkinan adanya penarikan kesimpulan dalam pengambilan tindakakan. (3) Kesimpulan dan verifikasi, yaitu data yang sudah diatur sedemikian rupa (dipolakan, difokuskan, disusun secara sistematis) kemudian disimpulkan sehingga makna data dapat ditemukan. Akan tetapi, kesimpulan tersebut hanya bersifat sementara dan umum.

\section{HASIL DAN PEMBAHASAN}

Sesuai dengan rumusan masalah yang sudah dikemukakan dalam sub bab pendahuluan, pada sub bab hasil dan pembahasan dibahas mengenai bentuk-bentuk nilai moral terhadap sesama manusia. Bentuk-bentuk nilai moral diurakan dalam temuan hasil dan pembahasan di bawah ini.

\section{a. Saling Membantu}

Saling membantu merupakan sikap yang sangat terpuji karena memberikan bantuan merupakan kewajiban manusia sebagai makhluk sosial. saling membantu merupakan kebaikan yang harus selalu dibiasakan. Kebiasaan saling membantu membuat hidup menjadi harmonis dan menimbulkan rasa peduli terhadap sesama. Dalam cerita rakyat di Banten, nilai moral saling membantu terlihat dalam cerita rakyat yang berjudul Masjid Terate Udik Yang Keramat, Legenda Batu Kuwung, serta Pangeran Pande Gelang, dan Putri Cadasari. Ketiga cerita tersebut menggambarkan 
adanya sikap saling membantu yang dilakukan oleh tokoh utama terhadap masyarakat sekitar.

Dalam cerita Masjid Terate Udik Yang Keramat digambarkan tokoh utama adalah seorang yang kaya raya bernama Ki Ahmad. Ki Ahmad adalah seorang ulama terpandang di Kampung Terate Udik. Ki Ahmad membantu warga sekitar dengan cara mewakafkan tanahnya untuk dijadikan sebuah musala. Selain itu, Ki Ahmad juga sering dimintai bantuan oleh warga sekitar untuk menyelesaikan perselisihan diantara warga dan diselesaikan di musala tersebut.

Nilai moral saling membantu juga ditemui pada cerita rakyat Legenda Batu Kuwung. Dalam cerita tersebut terdapat tokoh yang bernama Orang Sakti dan menyamar menjadi Si Pengemis dan membantu masyarakat sekitar untuk menyadarkan Saudagar yang kikir. Orang sakti tersebut membantu masyarakat dengan membuat Saudagar yang kikir menjadi lumpuh. Kelumpuhan tersebut membuat Saudagar menjadi insyaf dan tidak mengulangi perbuatannya. Setelah Saudagar tersebut menyadari kesalahannya, kemudian Ia menjadi orang yang dermawan dan membantu rakyat miskin. Ia membagi-bagikan tanah pertaniannya kepada petani miskin untuk digarap.

Cerita rakyat di Banten yang mengandung nilai moral saling membantu juga ditemukan pada judul Pangeran Pande Gelang dan Putri Cadasari. Cerita ini mengisahkan seorang pangeran bernama Pande Gelang yang sakti dan kesaktiannya dicuri oleh teman seperguruannya bernama Pangeran Cuihin. Selain mencuri kesaktian Pande Gelang, Pangeran Cuihin juga merubah Pande Gelang menjadi sesosok laki-laki tua dan merebut kekasihnya bernama Putri Cadasari. Nilai moral saling membantu dalam cerita ini digambarkan ketika Putri Arum (nama lain dari Putri Cadasari) jatuh pingsan karena kelelahan dalam perjalanan menuju tempat Pande Gelang. Melihat hal tersebut, Pande Gelang yang dibantu warga sekitar menolong Putri Arum dan membawanya ke salah satu rumah penduduk terdekat.

Nilai-nilai moral saling membantu yang terdapat dalam ketiga cerita rakyat tersebut sesuai dengan nilai moral terhadap sesama manusia yang dikemukakan oleh Suparno, dkk. Suparno, dkk (2002: 32) yang mengemukakan adanya sikap tenggang rasa, berlaku adil, suka mengabdi, ramah, setia, sopan, dan tepat janji. Sikap-sikap ini jelas membantu orang lain dalam berelasi dengan orang lain dan hidup bersama orang lain. Berlaku adil dan tenggang rasa merupakan wujud penghargaan kita terhadap orang 
lain, sesama kita. Sikap jujur sangat penting ditekankan terlebih dalam situasi Indonesia yang menjadi juara korupsi di dunia. Di dalam sekolah kejujuran dapat diwujudkan dalam tindakan seperti tidak menyontek, tidak melakukan plagiat, tidak korupsi, tidak main belakang, dan tidak membohongi teman.

\section{b. Jujur}

Jujur merupakan sikap keterusterangan pada perilaku dan tidak diiringi dengan kebohongan. Kejujuran dapat diartikan sebagai sikap yang dapat dipercaya, setia, adil, dan tulus. Selain itu jujur merupakan suatu kebajikan yang dijunjung oleh setiap etinis, agama, dan ras manapun. Kejujuran merupakan hal yang sangat penting di dalam kehidupan setiap individu.

Sikap jujur yang ditemukan dalam cerita rakyat di Banten yang berjudul Legenda Prasasti Mujul. Dalam cerita ini, sikap jujur ditunjukkan oleh tawanan anak buah bajak laut yang mengatakan bahwa pemimpinnya berbau amis dan mempunyai penyakit asma. Hal tersebut dilakukan agar pemimpinnya yang merupakan seorang bajak laut dapat tertangkap dan mengakhiri kejahatannya. Kejujuran yang dilakukan oleh tawanan tersebut menolong prajurit kerajaan yang ditugaskan untuk menangkap bajak laut tersebut berhasil dalam tugasnya.

Sikap jujur juga digambarkan dalam cerita yang berjudul Masjid Terate Udik Yang Keramat. Sikap jujur ditunjukkan oleh tokoh yang bernama Pak Tio. Pada awalnya Tio merupakan salah satu anak angkat Ki Ahmad. Pak Tio menyuruh Pak Randik menjadi saksi palsu atas perebutan tanah di belakang mushola yang tidak lain adalah tanah wakaf Ki Ahmad. Pak Tio merasa menyesal telah menyuruh Pak Randik untuk bersumpah palsu di hadapan seluruh warga desa. Ia pun akhirnya mengakui bahwa dirinya telah berdusta dan membuat surat wasiat palsu.

Kejujuran merupakan karakter utama yang idealnya dimiliki oleh setiap pribadi. Namun relitas menunjukkan fenomena ketidakjujuran justru merebak di masyarakat. Perilaku tidak jujur tersebut muncul pada berbagai lini, baik di kalangan siswa, mahasiswa, pegawai, bahkan pejabat. Kondisi tersebut membuat generasi muda kurang mendapatkan figur keteladanan dalam berperilaku jujur. Integritas pribadi seakan-akan menjadi hal langka yang hanya dapat ditemukan pada sedikit figur publik. Sementara itu berperilaku tidak jujur dianggap sebagai hal lumrah untuk mencapai tujuan yang diinginkan (Lestari dan Asyanti, 2015: 351). 
Nilai-nilai moral yang terdapat dalam kedua cerita di atas dapat digunakan sebagai media untuk memberikan pelajaran kepada anak-anak agar selalu berkata jujur dalam keadaana apapun. Anak harus belajar jujur agar hidupnya menjadi lebih tenang karena tidak mempunyai beban atas kebohongan yang diperbuat. Sikap jujur juga dapat memberikan dampak positif bagi kehidupan karena dapat membuat diri dipercaya oleh orang lain. Menurut Suparno, dkk (2002: 32) menyatakan bahwa di dalam sekolah kejujuran dapat diwujudkan dalam tindakan seperti tidak menyontek, tidak melakukan plagiat, tidak korupsi, tidak main belakang, tidak membohongi teman, dan lain-lain.

\section{c. Menghargai Orang Lain}

Menghargai orang lain merupakan salah satu sikap yang terpuji. Menghargai orang lain merupakan upaya untuk memberikan apresiasi terhadap orang lain. Apresiasi tersebut dapat berupa pujian, penghargaan, dan pemberian hak untuk mengemukakan pendapat. Dalam Kamus Besar Bahasa Indonesia Edisi Kelima, kata menghargai dapat diartikan sebagai menghormati dan mengindahkan. Oleh karena itu, menghargai orang lain juga dapat dilakukan dengan cara menghormati hak-hak orang lain dan toleransi.

Dalam cerita rakyat di Banten, ditemukan dalam cerita yang berjudul Masjid Terate Udik Yang Keramat. Dalam cerita tersebut dikisahkan bahwa ada tetangga baru di Kampung Terate Udik yang bernama Pak Fikar mengundang Ustadz Wahid untuk datang ke dalam acara syukuran. Meskipun Pak Fikar merupakan warga baru dan belum dikenal oleh warga sekitar, namun Ustadz Wahid beserta warga bersedia untuk memenuhi undangan tersebut.

Sikap warga masyarakat yang ditunjukkan dalam cerita Masjid Terate Udik Yang Keramat sesuai dengan pendapat Panjaitan, (2014: 89) yang menyatakan bahwa setiap orang hendaknya sadar bahwa seorang harus bisa dan mau menerima orang lain apa adanya, dalam arti tidak ada diskriminasi. Setiap orang harus mampu menerima seseorang dengan tidak membedakan suku, agama, bahasa, jenis kelamin, dan bangsanya. Setiap orang patut dan layak untuk dihargai dan dihormati. Penerimaan ini harus dilakukan dengan tulus dan penuh kesadaran. Jika seseorang mampu menerima orang lain apa adanya, orang itu pun akan diterima apa adanya. Layaknya hukum tabur tuai, apa yang ditabur seseorang, itu juga yang dituai orang tersebut. 
Sikap non diskriminatif dan non repsif (Suparno, dkk, 2002: 32) adalah wujud dari demokrasi. Dalam negara yang demokratis, orang tidak boleh didiskriminasikan berdasarkan suku, agama, tingkat sosial, maupun level pendidikan. Orang mendapatkan perlakuan sama dalam mendapatkan pelayanan masyarakat dan negara seperti dalam hal ini pendidikan dan hukum. Orang juga tidak boleh ditindas oleh orang atau kelompok lain, tetapi perlu dihargai. Penindasan dalam bentuk apa pun dianggap melanggar nilai kemanusiaan. Sikap ini perlu ditanamkan pada anak didik sehingga mereka sejak kecil tidak mendiskriminasikan dan menindas orang lain atau teman lain.

\section{d. Bertanggung Jawab}

Bertanggung jawab merupakan sebuah perilaku yang mampu menanggung atau memikul sebuah kepentingan yang ada di dalam dirinya. Bertanggung jawab juga dapat diartikan sebagai sikap seseorang ketika mengambil keputusan. Nilai moral tanggung jawab sangat penting untuk dimiliki oleh setiap orang karena dengan adanya sikap tanggung jawab, maka orang tersebut dapat dinilai kualitas atas dirinya. Dalam Kamus Besar Bahasa Indonesia, kata bertanggung jawab mempunyai arti berkewajiban menanggung dan memikul sebuah beban.

Sikap tanggung jawab dalam cerita rakyat di Banten juga terlihat dalam cerita Legenda Batu Kuwung dan Legenda Gunung Pinang. Legenda Batu Kuwung mengisahkan seorang saudagar kaya yang pada awal hidupnya sangat kikir dan tidak mau membantu masyarakat sekitar. Ketika itu ada seorang pengemis yang merupkaan jelmaan dari orang sakti ingin menguji saudagar kaya itu. Pengemis tersebut meminta makanan dan seketika saudagar kaya mengusirnya. Tidak lama setelah itu saudagar itu sakit dan hanya dapat disembuhkan jika ia mengubah tabiatnya. Sehingga, saudagar kaya itu berubah menjadi seorang yang dermawan dan bertanggung jawab. Sikap tanggung jawab tokoh saudagar kaya ditunjukkan dengan menikahi gadis cantik dari keluarga miskin dan menjalankan tugas menjadi kepada desa.

Menurut Suparno, dkk (2002: 35) Sikap khas manusia sebagai pribadi adalah dia punya kebebasan untuk mengungkapkan dirinya dan bertanggung jawab terhadap ungkapannya. Sikap ini berlaku baik terhadap diri sendiri, terhadap orang lain, dan juga terhadap alam dan Tuhan. Sikap ini jelas dapat diwujudkan dalam kebebasan mimbar, kebebasan bicara, kebebasan untuk mengungkapkan gagasan, dan tanggung jawab itu. Dalm konteks tanggung jawab juga menyangkut keputusan yang kita ambil terhadap 
orang lain dan diri sendiri. Kita harus bertanggung jawab terhadap keputusan yang telah kita ambil dengan pemikiran masak.

\section{e. Menghargai Perempuan}

Menghargai perempuan merupakan sikap yang harus dimiliki oleh setiap individu, khusunya laki-laki. Laki-laki tidak boleh bersikap semena-mena terhadap perempuan dan menganggap perempuan adalah makhluk lemah. Perempuan harus didudukan setara dengan laki-laki dan mendapatkan hak yang sama. Karena, baik perempuan maupun laki-laki mempunyai kedudukan yang sama di mata Tuhan.

Sikap menghargai perempuan terdapat dalam cerita Pangeran Pande Gelang dan Putri Cadasari. Cerita Pangeran Pande Gelang dan Putri Cadasari mengisahkan tentang seorang pemuda bernama Pande Gelang yang sakti dan tampan. Pande Gelang sangat menghormati dan berlaku sopan kepada perempuan. Pande Gelang sangat menghargai Putri Arum dan tidak mau membuatnya menjadi tidak nyaman ketika berada di dekatnya. Sikap menghargai tokoh Pande Gelang kepada Putri Arum yaitu ketika Putri Arum terkejut dengan kehadiran Pande Gelang, maka ia langsung meminta maaf karena membuat tidak nyaman Putri Arum.

Sikap tokoh Pande Gelang sangat sesuai dengan perwujudan nilai moral yang dikemukakan oleh Suparno, dkk (2002: 31) yang menyatakan bahwa salah satu wujud penghargaan terhadap setiap manusia adalah penghargaan terhadap perempuan (gender). Persoalan ini menjadi penting di zaman ini agar perempuan tidak didiskriminasikan terhadap laki-laki. Perempuan dan laki-laki diciptakan sederajat, mereka sama-sama bernilai di depan Tuhan. Oleh karena itu, perempuan tidak boleh direndahkan apalagi dilecehkan. Mereka harus dihargai sederajat dengan laki-laki; yang membedakan mereka adalah fungsinya. Dalam konteks ini maka perendahan derejat perempuan seperti pelacuran, penjualan perempuan, kekerasan terhadap perempuan, perkosaan hak perempuan, adalah melanggar kemanusiaan kita dan perlu ditentang.

\section{f. Menghormati Orang Tua}

Hormat merupakan sebuah sikap menghargai, takzim, dan khidmat kepada orang lain termasuk orang tua. Berbakti atau menghormati orang tua merupakan sebuah kewajiban yang harus dilakukan oleh seorang anak. Sikap menghormati orang tua merupakan sikap yang sangat terpuji dan dianjurkan oleh semua agama. 
Pada cerita rakyat di Banten, digambarkan sikap menghormati orang tua melalui tokoh Hasanuddin dalam cerita Sultan Maulana Hasanuddin. Dalam cerita ini, tokoh Hasanuddin digambarkan memiliki sikap hormat kepada orang tua. Hal tersebut terlihat pada saat Ayahnya, Syekh Syarif Hidayatullah. Saat ilmu agama yang dimiliki oleh Hasanuddin sudah cukup, ayahnya meminta ia untuk menyebarkan agama Islam ke penduduk wilayah Banten.

Hal tersebut juga selaras dengan pendapat Fawn (2016) yang menyatakan bahwa moral harus diterapkan oleh setiap individu. Salah satu bentuk nilai moral adalah menghormati orang tua. Menghormati orang tua merupakan bentuk moral yang perlu dijaga dan dilestarikan. Jika setiap individu menjaga hal tersebut, maka akan hubungan antara orang tua dengan anak akan seimbang.

Beberapa budaya mempunyai nilai hidup bersama yang dianggap baik. Nilai ini pun perlu ditawarkan kepada anak didik agar mereka dapat masuk dalam budaya mereka dan juga dapat mengerti budaya serta orang-orang mereka. Nilai sopan santun memang tidak berlaku umum, tetapi lebih ditentukan daerah masing-masing. Maka nilainya relatif. Namun meski relatif mempunyai kebaikan juga yang perlu diperkenalkan. Ada baiknya siswa dilatih kritis dengan nilai budaya mereka, sehingga kita tidak hanya ikut tetapi juga memperbaiki dan mengembangkannya. Mengapa nilai ini relatif, karena dalam budaya lain dapat berlainan. Misalnya, kesopanan menghormati orang tua. Nilai ini benar, tetapi ungkapannya dapat berbeda. Di Jawa, menghormati orang tua berarti kita tidak boleh membantah orang tua; sedangkan di budaya lain malah harus berani bicara dengan orang tua (Suparno, dkk, 2002: 24).

Tabel 1 Hasil dan Pembahasan

\begin{tabular}{|c|c|l|l|}
\hline NO & $\begin{array}{c}\text { BENTUK NILAI } \\
\text { MORAL }\end{array}$ & JUDUL CERITA & \multicolumn{1}{c|}{ KUTIPAN } \\
\hline \multirow{2}{*}{1} & Saling membantu & $\begin{array}{l}\text { Masjid Terate Udik Yang } \\
\text { Keramat }\end{array}$ & $\begin{array}{l}\text { Rumah ibadah tersebut didirikan di } \\
\text { atas tanah wakaf milik Ki Ahmad } \\
\text { yang merupakan sesepuh desa } \\
\text { sekaligus ulama yang terkenal kaya. }\end{array}$ \\
\cline { 3 - 4 } & Legenda Batu Kuwung & $\begin{array}{l}\text { Pada suatu hari, berita tentang } \\
\text { keangkuhan dan kesewenang- } \\
\text { wenangan saudagar kaya itu sampai } \\
\text { ke telingan seorang sakti } \\
\text { mandraguna. Orang sakti itu pun } \\
\text { bermaksud untuk menyadarkan sang } \\
\text { saudagar yang sombong dan kikir itu. }\end{array}$ \\
\hline
\end{tabular}




\begin{tabular}{|c|c|c|c|}
\hline & & $\begin{array}{l}\text { Pangeran Pande Gelang } \\
\text { dan Putri Cadasari }\end{array}$ & $\begin{array}{l}\text { Ia pun disarankan oleh gurunya untuk } \\
\text { membuat sebuah gelang besar yang } \\
\text { bisa dilewati manusia. Gelang itulah } \\
\text { yang dapat mengalahkan Pangeran } \\
\text { Cunihin. Jika Pangeran Cunihin } \\
\text { melewati gelang tersebut maka } \\
\text { seluruh kesaktiannya akan lenyap dan } \\
\text { kembali kepada Pangeran Sae Bagus. }\end{array}$ \\
\hline \multirow[b]{2}{*}{2} & \multirow[b]{2}{*}{ Jujur } & Legenda Prasasti Munjul & $\begin{array}{l}\text { Namun, salah seorang dari tawanan } \\
\text { itu memberitahukan mengenai ciri- } \\
\text { ciri pemimpin mereka yaitu berbau } \\
\text { amis dan berpenyakit asma. }\end{array}$ \\
\hline & & $\begin{array}{l}\text { Masjid Terate Udik Yang } \\
\text { Keramat }\end{array}$ & $\begin{array}{l}\text { Tio ketakutan karena merasa bersalah } \\
\text { telah menyuruh Pak Randik untuk } \\
\text { bersumpah palsu di hadapan seluruh } \\
\text { warga desa. Ia pun akhirnya } \\
\text { mengakui bahwa dirinya telah } \\
\text { berdusta dan membuat surat wasiat } \\
\text { palsu. }\end{array}$ \\
\hline 3 & Menghargai Orang Lain & $\begin{array}{l}\text { Masjid Terate Udik Yang } \\
\text { Keramat }\end{array}$ & $\begin{array}{l}\text { Pak Fikar adalah warga baru di desa } \\
\text { itu dan bermaksud mengajak Ustadz } \\
\text { Wahid untuk menghadiri menghadiri } \\
\text { acara syukuran di rumahnya. Ustadz } \\
\text { Wahid bersama beberapa warga } \\
\text { lainnya pun mengiyakan undangan } \\
\text { itu. }\end{array}$ \\
\hline & Bertanggung jawab & Legenda Batu Kuwung & $\begin{array}{l}\text { Setelah itu, ia menikahi seorang gadis } \\
\text { cantic dari keluarga miskin dan } \\
\text { kembali menjalankan tugas-tugasnya } \\
\text { sebagai kepala Desa dengan penuh } \\
\text { tanggung jawab. }\end{array}$ \\
\hline 4 & Bertanggung jawab & Legenda Gunung Pinang & $\begin{array}{l}\text { Untuk mengganti ongkos kapal, ia } \\
\text { ditugaskan oleh Teuku Abu Matsyah } \\
\text { membersihkan seluruh galangan } \\
\text { kapal. Dampu Awang sangat rajin dan } \\
\text { tekun bekerja. Tak heran jika ia } \\
\text { mendapat perhatian dari saudagar } \\
\text { kaya itu. }\end{array}$ \\
\hline 5 & $\begin{array}{l}\text { Sopan dan santun pada } \\
\text { orang lain terutama } \\
\text { perempuan }\end{array}$ & $\begin{array}{l}\text { Pangeran Pande Gelang } \\
\text { dan Putri Cadasari }\end{array}$ & $\begin{array}{l}\text { "Maaf jika hamba telah mengejutkan } \\
\text { Tuan Putri," kata Pande Gelang } \\
\text { seraya memberi hormat. }\end{array}$ \\
\hline 6 & Menghormati Orang Tua & $\begin{array}{l}\text { Sultan Maulana } \\
\text { Hasanuddin }\end{array}$ & $\begin{array}{l}\text { "Putraku, Hasanuddin! Kini Engkau } \\
\text { sudah dewasa. Pengetahuan agamamu } \\
\text { pun sudah cukup mumpuni. Saatnya } \\
\text { pengetahuan itu kau sebarkan kepada } \\
\text { seluruh rakyat Banten," ujar Syekh } \\
\text { Syarif Hidayatullah. } \\
\text { "Baik, Ayah," jawab Pangeran }\end{array}$ \\
\hline
\end{tabular}


Hasanuddin seraya berpamitan kembali ke Banten.

\section{E. KESIMPULAN}

Cerita rakyat merupakan sebuah media yang dapat digunakan untuk menanamkan nilai-nilai kebaikan yang ada di dalam kehidupan bermasyarakat. Salah satu nilai kebaikan yang dapat ditanamkan melalui cerita rakyat adalah nilai moral. Nilai moral merupakan pengajaran baik atau buruk perbuatan dan tingkah laku. Moral dapat digunakan sebagai alat ukur untuk menentukan baik dan buruknya akhlak atau perilaku seseorang. Oleh karena itu, pendidikan moral sangat penting untuk diajarkan karena menyangkut masa depan generasi selanjutnya.

Salah satu cerita rakyat yang mengajarkan nilai-nilai kebaikan atau moral adalah cerita rakyat di Banten. Ada enam judul cerita rakyat di Banten diantaranya Masjid Terate Udik yang Keramat, Legenda Batu Kuwung, Legenda Gunung Pinang, Pangeran Pande Gelang dan Putri Cadasari, Legenda Prasasti Mujul, dan Sultan Maulana Hasanuddin. Dari keenam cerita rakyat tersebut, ditemukan enam bentuk nilai moral yang berhubungan dengan sesama atau sikap terhadap sesama. Keenam bentuk nilai moral tersebut adalah saling membantu, jujur, menghargai orang lain, bertanggung jawab, menghargai perempuan, dan menghormati orang tua.

Dari keenam bentuk nilai moral yang digambarkan dalam cerita rakyat di Banten diharapkan dapat menjadi contoh bagi masyarakat. Masyarakat dapat mengambil nilai kebaikan tersebut dan ditanamkan dalam kehidupan sehari-hari. Selain itu, nilai moral yang terdapat dalam cerita rakyat di Banten dapat dijadikan contoh atau model bagi orang tua dalam membimbing anak agar menjadi pribadi yang baik.

\section{F. SARAN}

Sebuah penelitian pada dasarnya tidak berhenti pada satu sudut pandang saja. Oleh karena itu, untuk peneliti selanjutnya, diharapkan dapat mengembangkan penelitian ini agar lebih bervariasi temuan yang didapat. Meskipun dengan objek yang sama, diharapakan peneliti selanjutnya mampu mengembangkan permasalahan yang diangkat. Tidak menutup kemungkinan bahwa penelitian selanjutnya akan membahas dengan menggunakan teori yang sama. Akan tetapi, diharapkan jika menggunakan teori yang sama maka objek kajian harus lebih bervariasi agar dapat menambah temuan yang sudah ada sebelumnya. 


\section{DAFTAR PUSTAKA}

Arrows, F. (2016). The CAT-FAWN connection: Using metacognition and Indigenous worldview for more effective character education and human survival. Journal of Moral Education, 45(3), 261-275.

Eliastuti, M. (2018). ANALISIS NILAI-NILAI MORAL DALAM NOVEL "KEMBANG TURI" KARYA BUDI SARDJONO. Genta Mulia: Jurnal Ilmiah Pendidikan, 8(1).

http://ceritarakyatnusantara.com/id/browse/335-Banten\# diakses pada tanggal 13 Oktober 2019.

Lestari, S., \& Asyanti, S. (2015). Apakah Siswa SMP Berperilaku Jujur dalam Situasi Ulangan?.

Mada, F. (2017). NILAI MORAL DALAM CERITA RAKYAT WA ODE KAENGU FAARI DAN LA SIRIMBONE PADA MASYARAKAT MUNA. JURNAL BASTRA, I(4).

Nurdyansyah, N. (2018). Peningkatan Moral Berbasis Islamic Math Character. Universitas Muhammadiyah Sidoarjo.

Nurfajriah, S. (2014). Nilai Moral dalam Novel Orang Miskin Dilarang Sekolah Karya Wiwid Prasetyo dan Implikasinya Terhadap Pembelajaran Bahasa dan Sastra Indonesia di Sekolah.

Panjaitan, H. (2014). Pentingnya Menghargai Orang Lain. Humaniora, 5(1), 88-96.

Simamora, Dose Mega (2018). Nilai-Nilai Moral Cerita Rakyat Kerincidalam Buku Kunaung. Jambi: Skripsi Program Studi Sastra Indonesiafakultas Ilmu Budaya Universitas Jambi.

Suparno, Paul, Moerti Yoedho Koesoemo, Detty Titisari, St. Kartono. (2002). Pendidikan Budi Pekerti - Suatu Tinjauan Umum. Yogyakarta: Kanisius.

Youpika, F., \& Zuchdi, D. (2016). Nilai pendidikan karakter cerita rakyat Suku Pasemah Bengkulu dan relevansinya sebagai materi pembelajaran sastra. Jurnal Pendidikan Karakter, (1). 